\title{
Distribution of Myxomycetes on Varied Leaf Litter Types in a Mixed Forest in Warm-Temperate Western Japan
}

\author{
Kazunari Takahashi \\ Okayama University of Science Senior High School, Okayama City, Japan \\ Email: kumakusu03@yahoo.co.jp
}

Received 15 August 2015; accepted 27 September 2015; published 30 September 2015

Copyright (C) 2015 by author and Scientific Research Publishing Inc.

This work is licensed under the Creative Commons Attribution International License (CC BY). http://creativecommons.org/licenses/by/4.0/

(c) (i) Open Access

\begin{abstract}
Myxomycete assemblages were compared on various leaf litters of different vegetation types in a local mixed forest consisting of deciduous and evergreen trees in western Japan. A total of 33 myxomycete species were recorded and associated with the chemical and biological environments of leaf litters under natural condition of the forest floor. Different myxomycete assemblages were found on different sites under the dominant trees in a short distance apart (300 m). A site of Prunus jamasakura tree yielded 21 species, a Quercus glauca tree yielded 20 species, an Ilex pedunculosa tree yielded 12 species, and two Quercus serrata trees yielded 13 and 14 species, respectively. Non-metric multidimensional scaling demonstrated that the myxomycete assemblages were closely related to the litter types of deciduous and evergreen trees, and both litter $\mathrm{pH}$ and cellulolytic activity influenced distribution of myxomycete species. Species richness was higher in leaf litters with higher $\mathrm{pH}$ than in leaf litters with more acidic $\mathrm{pH}$ such as I. pedunculosa litter. The dominant tree litter and litter pH strongly influenced the species distribution of foliicolous myxomycetes in a local mixed forest.
\end{abstract}

\section{Keywords}

Cellulolytic Activity, Dominant Trees, Foliicolous Myxomycetes, Litter pH

\section{Introduction}

Myxomycetes (also known as plasmodial slime molds) are eukaryotic amoebozoid microorganisms that inhabit terrestrial ecosystems (Madelin, 1984). In warm-temperate forests, myxomycetes are usually found on decaying plant material, such as wood logs, leaf litter, bark, and soil (Ing, 1994) and are considered to play a significant 
role in food chain nutrient cycling of woodland detritus (Madelin, 1984; Rayner \& Boddy, 1988). However, it has remained poorly understood that differences of leaf litter type in a mixed forest influence the distribution of myxomycetes.

Distributional scale of myxomycetes is regulated by major vegetation types along altitudinal gradients (Rojas \& Stephenson, 2008; Ndiritu et al., 2009). Previous studies in temperate regions have shown that myxomycete assemblages associated with coniferous tree litter are distinctly different from those associated with broad leaf tree litters (Härkönen, 1981; Stephenson, 1989). In the tropical forests of northern Thailand, litters of two species of trees were particularly favorable substrates for many species of myxomycetes (Tran et al., 2006). Takahashi (2013) subsequently documented that myxomycete assemblages differed between deciduous broadleaf and evergreen tree leaf litters in local woodlands of warm-temperate Japan. However, not much is known about how dominant trees in a forest influence the heterogeneous habitats of myxomycetes and promote species diversification in a forest.

In mixed forests in the warm-temperate regions in Japan, leaf litter types vary according to the dominant tree species. These dominant tree patches may provide myxomycetes with heterogeneous varied habitats that differ in physicochemical characteristics and decomposition rates (Takeda et al., 1984; Berg \& McClaugherty, 2010). Thus, I hypothesized that in a mixed forest floor, the leaf litters of different tree species supported different myxomycete assemblages. The goal of this study was to find out the difference of myxomycetes inhabiting leaf litters (not soil) in a particular area of a mixed forest. To evaluate the variations of myxomycete ecology and to determine the micro-distribution of the species, according to the leaf litter types, may deduce the existence of micro-ecosystems in a forest.

\section{Materials and Methods}

\subsection{Study Site}

The study sites were located in the Himeji Nature Sanctuary, which covers 59 ha of a typical mixed secondary forest in Oichinaka, Himeji City, Hyogo Prefecture $\left(34^{\circ} 51.33^{\prime} \mathrm{N}, 134^{\circ} 37.18^{\prime} \mathrm{E}\right)$, along an altitudinal gradient from 60 to $196 \mathrm{~m}$ above sea level. The forest crown reached approximately $18 \mathrm{~m}$ in height and mainly consisted of deciduous Quercus serrata Murray mixed with Prunus jamasakura Sieb. et Koisz. trees, evergreen Quercus glauca Thunb., and Ilex pedunculosa Miq. trees, and sparsely distributed coniferous Pinus densiflora Sieb. \& Zucc. trees (Figure 1(A)). The sub-canopy and shrub layers were dominated by Q. serrata and Clethra barbinervis Sieb. et Zucc. interspersed with Eurya japonica Thunb. and young Q. glauca. Five investigation sites were

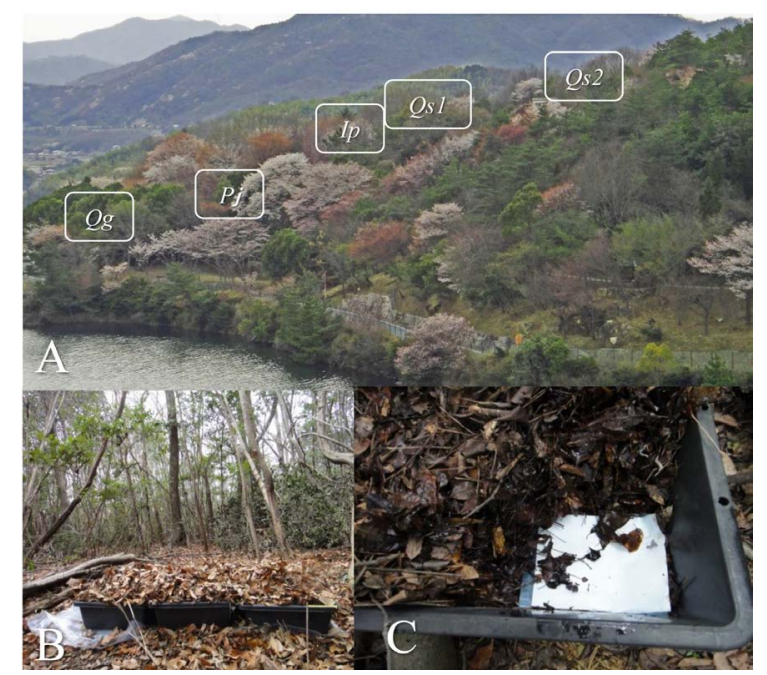

Figure 1. Mixed vegetation at the study sites and the leaf litter incubation method on the forest floor. (A) location of the five sites, showing dominant trees: Qg, Quercus glauca; Pj, Prunus jamasakura; Ip, Ilex pedunculosa; and Qs1/ Qs2, Quercus serrata; (B) containers with leaf litter placed on a plastic film; and (C) filter paper in a mesh bag at the bottom of the leaf litter container. 
located on the forest floor under the dominant trees of Q. glauca, P. jamasakura, I. pedunculosa and Q. serrata (two different sites) growing within $300 \mathrm{~m}$ of one another on a south-western slope at 60 to $100 \mathrm{~m}$ above sea level. Those sites were topographically settled along a short gentle slope in a mixed forest. The composition of deciduous and evergreen vegetation and tree coverage at the investigation sites $(5: \geq 75 \%, 4: \geq 50 \%, 3: \geq 25 \%, 2$ : $\geq 10 \%, 1: \geq 1 \%$ in a square of $10 \mathrm{~m} \times 10 \mathrm{~m}$ ) are presented in Table 1 .

At a nearby study site, annual precipitation was $1465.5 \mathrm{~mm}$, and mean annual temperature was $15.5^{\circ} \mathrm{C}(2013$, Japan Meteorological Agency observation point, $34^{\circ} 50.3^{\prime} \mathrm{N}, 134^{\circ} 40.2^{\prime} \mathrm{E}, 38.2 \mathrm{~m}$ above sea level).

\subsection{Leaf Litter Incubation}

The freshly shed litters on the ground were collected from the ambient area under dominant forest-crown trees during two defoliated seasons. Annual defoliation from trees provides fresh habitat and nutrition for myxomycetes (Takahashi, 2011). Approximately 200 liters each of leaf litter were collected from deciduous trees $(Q$. serrata and P. jamasakura) in early February and from evergreen trees (Q. glauca and I. pedunculosa) in late April. Twigs over $5 \mathrm{~mm}$ in diameter were removed from the litter mass. The litters were incubated in three or six 60 -liter containers $(96 \times 69 \times 20 \mathrm{~cm})$ according to the in situ incubation method (Takahashi, 2013) at the collection sites (Figure 1(B)). Litter masses in the incubation containers maintained moderately more moisture than on the ambient ground, increasing the growth potential of myxomycetes in the leaf litters during field season from April to November. The collected leaf litters in the containers were hospitable to myxomycetes and the study design allowed the myxomycete species to be recognized despite their exiguous fruiting bodies and ephemeral existence. For the incubation experiments and measurements, six or nine replicates of container were carried out in each site during 2012 and 2013 (Table 2).

\subsection{Measurements of $\mathrm{pH}$ and Cellulolytic Activity in the Leaf Litters}

It is well known that myxomycetes inhabiting tree bark are remarkably responsive to bark pH (e.g., Everhart et al., 2008). Myxomycetes use bacteria and organic matter as nutrient resources (Madelin, 1984); thus, the cellulolytic activity of microorganisms associated with the decomposition of leaf litter was expected to promote the presence of myxomycetes. The $\mathrm{pH}$ of the percolated liquid at the bottom of containers was measured twice in July at three points within each container, using a compact pH meter (Horiba Twin, HORIBA Ltd., Kyoto, Japan); tree species-specific ranges of $\mathrm{pH}$ variations and median are shown in Table 2.

Table 1. Vegetation of five investigation sites on the slope of a mixed forest in the Himeji Nature Sanctuary.

\begin{tabular}{|c|c|c|c|c|c|}
\hline & \multicolumn{5}{|c|}{ Investigation sites $^{\mathrm{a}}$} \\
\hline & \multicolumn{2}{|c|}{ Evergreen } & \multicolumn{3}{|c|}{ Deciduous } \\
\hline & $Q g$ & $I p$ & $P j$ & $Q s 1$ & $Q s 2$ \\
\hline Altitude (m) & 65 & 100 & 75 & 105 & 130 \\
\hline Height of tree layer (m) & 13 & 14 & 18 & 14 & 11 \\
\hline \multicolumn{6}{|l|}{ Number of tree species } \\
\hline Total & 3 & 6 & 9 & 5 & 3 \\
\hline Coniferous trees & 1 & 1 & 0 & 0 & 1 \\
\hline Deciduous trees & 0 & 3 & 4 & 3 & 1 \\
\hline Evergreen trees & 2 & 2 & 5 & 2 & 1 \\
\hline \multicolumn{6}{|l|}{ Cumulative cover value } \\
\hline Coniferous trees & 1 & 1 & 0 & 0 & 2 \\
\hline Deciduous trees & 0 & 3 & 7 & 6 & 5 \\
\hline Evergreen trees & 7 & 6 & 6 & 3 & 2 \\
\hline
\end{tabular}

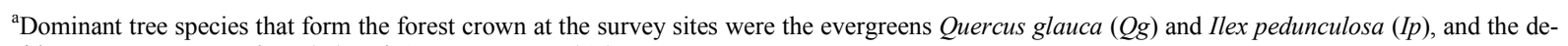
ciduous Prunus jamasakura $(P j)$ and Quercus serrata $(Q s)$. 
Table 2. Abundance of occurrence, species richness and diversity associating with environmental variables in the five investigation sites.

\begin{tabular}{|c|c|c|c|c|c|c|}
\hline & \multicolumn{5}{|c|}{ Investigation sites ${ }^{\mathrm{a}}$} & \multirow[b]{3}{*}{ Total } \\
\hline & \multicolumn{2}{|c|}{ Evergreen } & \multicolumn{3}{|c|}{ Deciduous } & \\
\hline & $Q g$ & $I p$ & $P j$ & $Q s 1$ & $Q s 2$ & \\
\hline Containers & 9 & 6 & 9 & 6 & 6 & 36 \\
\hline Abundance/container & 52 & 23 & 40 & 28 & 36 & 37 \\
\hline Species richness & 20 & 12 & 21 & 13 & 14 & 33 \\
\hline Estimated species (Chao-1) & 23 & 22 & 32 & 13 & 17 & 44 \\
\hline Species diversity $H^{\prime}$ & 1.96 & 1.85 & 1.80 & 2.01 & 1.95 & 2.65 \\
\hline Evenness $J^{\prime}$ & 0.65 & 0.74 & 0.59 & 0.78 & 0.74 & 0.76 \\
\hline \multicolumn{7}{|l|}{ Environmental variables } \\
\hline Range of litter $\mathrm{pH}$ & $5.9-6.4$ & $4.3-5.1$ & $5.4-6.1$ & $5.4-5.7$ & $5.6-5.9$ & - \\
\hline Median of $\mathrm{pH}$ & 5.9 & 4.5 & 5.6 & 5.6 & 5.7 & \\
\hline Cellulolytic activity $(\mathrm{mg} / \text { day })^{\mathrm{b}}$ & 46 & 5 & 37 & 17 & 40 & - \\
\hline
\end{tabular}

${ }^{\mathrm{a}}$ Investigation sites show in Table 1. ${ }^{\mathrm{b}}$ Dry weight loss of filter paper measured during the early decomposition phase.

The cellulolytic activity was measured using the bench-coat filter paper method in the leaf litters (Yamamoto et al., 1991). Briefly, five filter paper sheets $(18 \times 23 \mathrm{~cm}$, dry weight $6.25 \mathrm{~g})$ were placed in 2-mm mesh nylon bags and placed at the bottom of litter containers at the beginning of the incubation period (Figure 1(C)). Paper mass loss was measured during the early decomposition phase from April to the end of July. The filters were dried at $70^{\circ} \mathrm{C}$ and weighed; decomposition rates were calculated as dry weight loss per day of experimental time (Table 2).

\subsection{Sampling and Identification of Myxomycetes}

Myxomycete fruiting bodies were observed in the leaf litter at five sites with the naked eye and loupes at approximately 2-week intervals from April to November for 2 years (2012-2013). Fruiting bodies were removed from the containers, allowed to dry, and glued inside a small paper box for long-term storage. The myxomycete occurrence was quantified as the number of leaves and/or twigs with three or more adhered sporocarps (considered one sample). If myxomycete sporocarps were found on a leaf fragment $\leq 1 \mathrm{~cm}^{2}$ or on a twig $\leq 1 \mathrm{~cm}$, the samples were excluded from the analyses. Normally, a single leaf contained only one myxomycete species, although a few samples with mixed species were observed. Morphological traits of the fruiting bodies that presented only a single character for classification were examined under a stereomicroscope and light microscope for species identification, referring to Yamamoto (1998) and Lado (2005-2015).

\subsection{Analysis of Myxomycete Assemblages}

The numbers of samples and species were compared among the five sites during the surveyed period and the relative myxomycete abundance was calculated as the proportion of positive samples to the total number of samples collected at an individual site. The species diversity in myxomycete assemblages was evaluated using the Shannon-Weiner index (Shannon \& Weaver, 1963), calculated as $H^{\prime}=\sum_{i=1}^{S} P i L n P i$, where $i$ is the relative abundance of species and $P i$ is the proportion of samples containing $i$ species. In addition, the evenness component $\left(J^{\prime}\right)$ of species diversity was calculated using Pielou's index (Pielou, 1966): $J^{\prime}=H^{\prime} / L n S$, where $S$ is the number of species present in the assemblage. When species are distributed evenly, $J$ has a value of 1 . The simplest nonparametric estimator Chao 1 (Chao, 1984) was used to calculate the presumed species richness of a sample. 
The ordination of myxomycete assemblages was evaluated by non-metric multidimensional scaling (NMDS; Kenkel \& Orloci, 1986) using the PAST software (Hammer et al., 2001; http://folk.uio.no/ohammer/past/). This computer application program was chosen because of its efficacy in other studies. NMDS provided to be the best strategy for recovering simulated two-dimensional gradient (Takahashi, 2010). Myxomycete assemblages were compared using the Jaccard similarity coefficient (Jaccard, 1912). To show the assemblage linkages amidst certain habitat similarity, the scores of the first two NMDS axes were plotted and each assemblage was arranged in order on the first and second axis. The relationships between their MNDS values and several environmental variables, such as altitude, deciduous tree cover, evergreen tree cover, number of tree species, cellulolytic activity and litter $\mathrm{pH}$ were analyzed using correlation coefficients. Correlation of the observations with species relative abundance and environmental variables was calculated using Excel version 5.0 (Esumi Co. Ltd., 2001).

\section{Results}

\subsection{Myxomycete Occurrence in Five Different Leaf Litters}

The leaf litters of the five sites yielded a total of 1348 myxomycete-positive samples in two entire field seasons, containing 33 species (varieties were treated as species) (Table 2). Among these, 21, 20, and 12 species were identified at P. jamasakura, Q. glauca, and I. pedunculosa tree sites, respectively, while 13 and 14 species were found in the two $Q$. serrata tree sites, respectively (the latter of which also contained pine litter). Species richness was the highest at the P. jamasakura litter site, which had the highest variety of tree species, including both deciduous and evergreen.

The exactitude of observed species richness was the highest at one of the $Q$. serrata sites (100\%; Sobs 13 species/Sest 13 species) and lowest at the $I$. pedunculosa site (54.5\%; Sobs 12 species/Sest 22 species). The $I$. pedunculosa site was presumed to have greater species richness. Species diversity at the Q. serrata1 site was the highest, as evidenced by the Shannon-Weiner index $H^{\prime}$ of 2.01 , with species evenness $J^{\prime}$ of 0.78 , followed by the Q. glauca site with $H^{\prime}$ of 1.96 and $J^{\prime}$ of 0.65 , while the P. jamasakura site had the lowest $H^{\prime}$ of 1.80 and $J^{\prime}$ of 0.59 (Table 2). Particular species occurred abundantly at the P. jamasakura site among the 21 species noted there.

A total of 20 species were frequently observed in five or more samples (Table 3). An examination of 100 samples revealed that five myxomycete species had the highest abundance (accounting for 7.4\% of the total): Physarum melleum, Physarum cinereum, Craterium minutum, Didymium squamulosum, and Didymium nigripes. These species either commonly appeared at all five sites or were abundant at a particular site. Species composition in myxomycete assemblages varied depending on the litter type, reflecting myxomycete substrate specificity. Didymium and/or Diderma species were abundant in the litters of evergreen species, while Physarum species abounded in deciduous tree litters (Figure 2). The Comatricha and Collaria species were relatively rare on leaf litters.

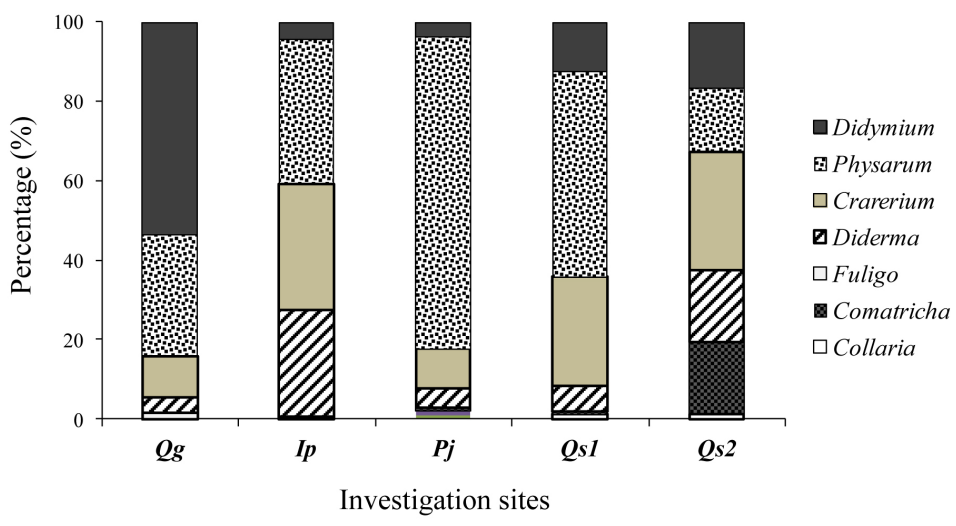

Figure 2. Genus composition (\%) of myxomycete at the five investigation sites of $Q g$ (dominant tree species of Quercus glauca), Pj (dominant tree species of Prunus jamasakura), Ip (dominant tree species of Ilex pedunculosa), Qs (dominant tree species of Quercus serrata). 
Table 3. Myxomycete species and number of samples observed on five investigation sites in the mixed forest.

\begin{tabular}{|c|c|c|c|c|c|c|}
\hline \multirow{2}{*}{ Myxomycete species ${ }^{\mathrm{a}}$} & \multicolumn{2}{|c|}{ Evergreen } & \multicolumn{3}{|c|}{ Deciduous } & \multirow{2}{*}{$\begin{array}{c}\text { Total } \\
\text { samples }\end{array}$} \\
\hline & $Q g$ & $I p$ & $P j$ & $Q s 1$ & $Q s 2$ & \\
\hline Physarum melleum (Berk. \& Broome) Massee & 14 & 16 & 192 & 4 & 3 & 229 \\
\hline Physarum cinereum (Batsch) Pers. & 122 & 1 & 44 & 18 & 27 & 212 \\
\hline Craterium minutum (Leers) Fries & 39 & 42 & 14 & & 61 & 156 \\
\hline Didymium squamulosum (Alb. \& Schwein.) Fr. \& Palmquist & 119 & & & & & 119 \\
\hline Didymium nigripes (Link) Fr. & 108 & & & & & 108 \\
\hline Craterium leucocephalum var. cylindricum (Massee) G. Lister & 7 & 1 & 21 & 47 & 3 & 79 \\
\hline Diderma saundersii (Massee) Lado & 7 & & 16 & 11 & 39 & 73 \\
\hline Physarum bivalve Pers. & & & 23 & 44 & 1 & 68 \\
\hline Physarum roseum Berk. \& Broome & & 32 & 4 & 19 & 1 & 56 \\
\hline Comatricha pulchella (C. Bab.) Rostaf. & 1 & & 4 & 1 & 39 & 45 \\
\hline Didymium serpula Fr. & 6 & 1 & 1 & 2 & 22 & 32 \\
\hline Didymium minus (Lister) Morgan & 3 & & 6 & 7 & 12 & 28 \\
\hline Diderma effusum (Schwein.) Morgan & 11 & 13 & 1 & & & 25 \\
\hline Physarum serpula Morgan & 4 & & 19 & & 1 & 24 \\
\hline Diderma simplex (J. Schröt.) E. Sheld. & & 19 & & & & 19 \\
\hline Didymium iridis (Ditmar) Fr. & 8 & 4 & 3 & & & 15 \\
\hline Didymium melanospermum (Pers.) T. Macbr. & 2 & & 2 & 10 & & 14 \\
\hline Physarum oblatum T. Macbr & & & 4 & 3 & 1 & 8 \\
\hline Fuligo gyrosa (Rostaf.) E. Jahn & 5 & 1 & & & & 6 \\
\hline Collaria rubens (Lister) Nann.-Bremek. & & & & 2 & 3 & 5 \\
\hline Diderma darjeelingense K.S. Thind \& H.S. Sehgal & & 4 & & & & 4 \\
\hline Didymium megalosporum Berk. \& M. A. Curtis & & & & 2 & 2 & 4 \\
\hline Lamproderma scintillans (Berk. \& Broome) Morgan & & & 4 & & & 4 \\
\hline Craterium paraguayense (Speg.) G. Lister & 3 & & & & & 3 \\
\hline Didymium flexuosum Yamash. & 3 & & & & & 3 \\
\hline Didymium leoninum Berk. \& Broome & & 1 & 1 & & & 2 \\
\hline Arcyria cinerea (Bull.) Pers. & & & 1 & & & 1 \\
\hline Craterium aureum (Schumach.) Rostaf. & & & 1 & & & 1 \\
\hline Diachea leucopodia (Bull.) Rostaf. & & & 1 & & & 1 \\
\hline Diachea subsessilis Peck & & & 1 & & & 1 \\
\hline Fuligo cinerea (Schwein.) Morgan & 1 & & & & & 1 \\
\hline Physarum bogoriense Racib. & 1 & & & & & 1 \\
\hline Physarum leucophaeum Fr. \& Palmquist & 1 & & & & & 1 \\
\hline
\end{tabular}

${ }^{a}$ Investigation sites show dominant tree species that consists of the tree layer. Quercus glauca $(Q g)$, Ilex pedunculosa (Ip), Prunus jamasakura (Pj), Quercus serrata $(Q s)$. 
Litter $\mathrm{pH}$ and decomposing activity were compared among the five sites. The Q. glauca, P. jamasakura, and $Q$. serrata sites had higher $\mathrm{pH}$ and levels of cellulose-decomposing activity, compared with the I. pedunculosa litter which showed little decomposition (Table 2). The $\mathrm{pH}$ levels significantly affected litter decomposition activity $(r=0.918, p<0.05)$, and myxomycete abundance increased with litter $\mathrm{pH}$ and decomposition activity. Myxomycete assemblages differed on different litter types, even though the litter types were found within a short distance of one another $(300 \mathrm{~m})$ in mixed forest.

\subsection{Ordination of Myxomycete Assemblages}

Five myxomycete assemblages demonstrated a distinct hierarchical ranking along the ordination axes of a twodimensional NMDS ordination (Figure 3). The coefficient of determination $\left(r^{2}\right)$ of the first axis was 0.598 and that of the second axis was 0.392. Among the environmental variables that were examined, the first axis was correlated with deciduous $(r=0.644)$ and evergreen $(r=-0.845)$ cover, whereas the second axis was significantly correlated with litter $\mathrm{pH}(\rho=-0.900, p<0.05)$, and decomposition rate $(\rho=-0.700)$. The number of tree species and the altitudinal location did not significantly influence the arrangement of the five assemblages. The deciduous and evergreen tree sites demonstrated a remarkable difference in myxomycete species composition. Dominant tree litter composition and litter $\mathrm{pH}$ strongly influenced the species distribution of myxomycetes in the mixed forest.

\subsection{Species Response to Microenvironment Variables}

The correlation between myxomycete abundance and microenvironment variables were examined for 20 species that were identified in five or more samples at the five sites (Table 4). Both P. melleum and Physarum serpula showed a significant positive correlation with the number of tree species growing in a site. The abundance of Physarum oblatum preferred evergreen tree litters. Fuligo gyrosa, D. nigripes, and D. squamulosum were significantly negatively correlated with the amount of deciduous tree cover, whereas Collaria rubens, Didymium minus, Didymium serpula, and Comatrica pulchella, which favored deciduous tree litters, showed a significant negative correlation with the amount of evergreen tree cover. On the other hand, Didymium iridis and F. gyrosa growth was positively correlated with the amount of evergreen tree cover.

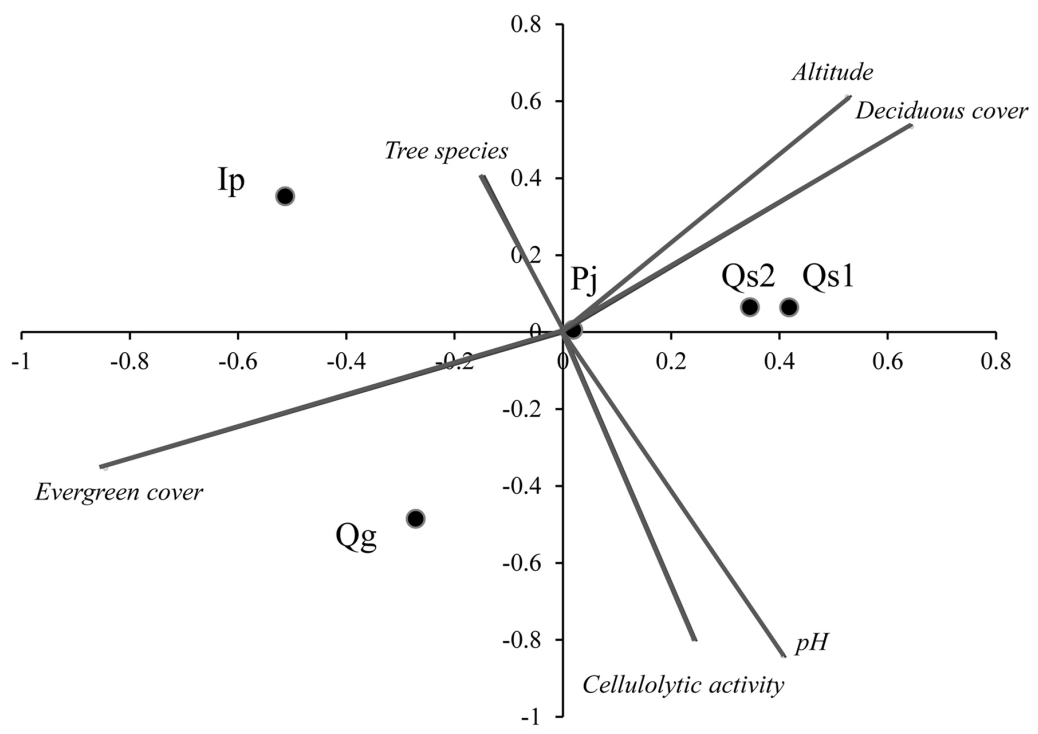

Figure 3. NMDS ordination diagram of myxomycete assemblage distribution on five different leaf litters in a mixed forest. Lines indicate the direction and strength of the important microenvironmental variables. The $r^{2}$ values of the first and second axes were 0.598 and 0.392 , respectively. The first axis is primarily correlated with deciduous cover $(r=0.644)$, evergreen cover $(r=-0.845)$, altitude $(r=0.525)$, number of tree species $(r=0.147)$, pH $(r=0.406)$, and decomposition rate $(r=$ $0.241)$. The second axis had a significant Spearman's correlation with litter $\mathrm{pH}(\rho=-0.900, p<0.05)$, decomposition rate $(\rho$ $=-0.700)$, altitudinal location $(\rho=0.700)$, deciduous cover $(\rho=0.000)$, evergreen cover $(\rho=-0.564)$, and number of tree species $(\rho=0.154)$. Qg, Quercus glauca; Pj, Prunus jamasakura; Ip, Ilex pedunculosa; Qs, Quercus serrata. 
Table 4. Correlation rates between relative abundance of twenty species and environmental factors.

\begin{tabular}{|c|c|c|c|c|c|}
\hline \multirow[b]{2}{*}{ Myxomycete species } & \multirow{2}{*}{$\begin{array}{l}\text { Number of } \\
\text { tree species }\end{array}$} & \multicolumn{2}{|c|}{ Vegetation cover } & \multicolumn{2}{|c|}{ Leaf litter } \\
\hline & & $\begin{array}{l}\text { Deciduous } \\
\text { tree }\end{array}$ & $\begin{array}{l}\text { Evergreen } \\
\text { tree }\end{array}$ & $\mathrm{pH}$ & $\begin{array}{l}\text { Decomposition } \\
\text { rate }\end{array}$ \\
\hline Physarum melleum & $0.915^{\mathrm{a}}$ & 0.519 & 0.400 & 0.179 & 0.123 \\
\hline Physarum serpula & $0.767^{\mathrm{a}}$ & 0.463 & 0.357 & 0.460 & 0.407 \\
\hline Physarum oblatum & 0.370 & $0.784^{\mathrm{a}}$ & -0.477 & 0.185 & -0.140 \\
\hline Fuligo gyrosa & -0.348 & $-0.953^{\mathrm{a}}$ & $0.734^{\mathrm{a}}$ & -0.085 & 0.017 \\
\hline Didymium nigripes & -0.494 & $-0.846^{\mathrm{a}}$ & 0.567 & 0.539 & 0.551 \\
\hline Didymium squamulosum & -0.494 & $-0.846^{\mathrm{a}}$ & 0.567 & 0.539 & 0.551 \\
\hline Didymium iridis & 0.138 & -0.605 & $0.763^{\mathrm{a}}$ & -0.531 & -0.400 \\
\hline Collaria rubens & -0.468 & 0.411 & $-0.980^{\mathrm{a}}$ & 0.038 & 0.017 \\
\hline Didymium minus & -0.349 & 0.524 & $-0.955^{\mathrm{a}}$ & 0.223 & 0.214 \\
\hline Didymium serpula & -0.572 & 0.102 & $-0.732^{\mathrm{a}}$ & 0.104 & 0.355 \\
\hline Comatricha pulchella & -0.461 & 0.202 & $-0.730^{\mathrm{a}}$ & 0.120 & 0.370 \\
\hline Physarum cinereum & -0.451 & -0.476 & 0.240 & $0.891^{\mathrm{a}}$ & $0.853^{\mathrm{a}}$ \\
\hline Physarum roseum & 0.194 & -0.043 & 0.094 & $-0.951^{\mathrm{a}}$ & $-0.969^{\mathrm{a}}$ \\
\hline Diderma simplex & 0.180 & -0.242 & 0.309 & $-0.912^{\mathrm{a}}$ & $-0.774^{\mathrm{a}}$ \\
\hline Diderma effusum & 0.086 & -0.452 & 0.477 & $-0.803^{\mathrm{a}}$ & $-0.657^{\mathrm{a}}$ \\
\hline Physarum bivalve & 0.161 & 0.523 & -0.417 & 0.028 & -0.334 \\
\hline Craterium leucocephalum var. cylindricum & 0.093 & 0.470 & -0.427 & 0.025 & -0.334 \\
\hline Didymium melanospermum & -0.001 & 0.367 & -0.409 & 0.014 & -0.341 \\
\hline Craterium minutum & -0.288 & -0.244 & -0.152 & -0.620 & -0.263 \\
\hline Diderma saundersii & -0.388 & 0.404 & -0.865 & 0.224 & 0.362 \\
\hline
\end{tabular}

${ }^{\mathrm{a}}$ Significance $p<0.01$.

Litter $\mathrm{pH}$ was positively correlated with the abundance of $P$. cinereum (Figure 4(A)) but negatively correlated with that of P. roseum (Figure 4(B)), Diderma simplex (Figure 4(C)), and D. effusum (Figure 4(D)). A similar correlation was observed between the abundance of the four species and cellulose decomposition rate. Thus, the distribution of 15 species showed a remarkable association with the biological and physiochemical parameters of their environment.

\section{Discussion}

\subsection{Myxomycete Distribution in a Mixed Forest}

Globally, myxomycete spores are dispersed by the wind (Kamono et al., 2009), whereas the sensitivity of these organisms to substrate types serve as the basis for species distribution at a local scale (Takahashi, 2013). The distribution patterns of microorganisms are suggested to be similar to those known from higher plants and animals (Foissner, 2006). Thus, we may expect that species will respond to environmental variables reflected by the nature of the dominant trees in a forest. A mixed forest in warm-temperate western Japan produces varied leaf litters that are densely inhabited by myxomycetes, as evidenced by an in situ incubation assessment (Takahashi, 2013). Myxomycetes grew in the litter masses and achieved complete life cycles. The present study revealed that the freshly shed leaves of dominant trees composing the forest crown provided myxomycetes with different habitats. The differences in the chemical and biological characteristics of the leaf litters influenced myxomycete 


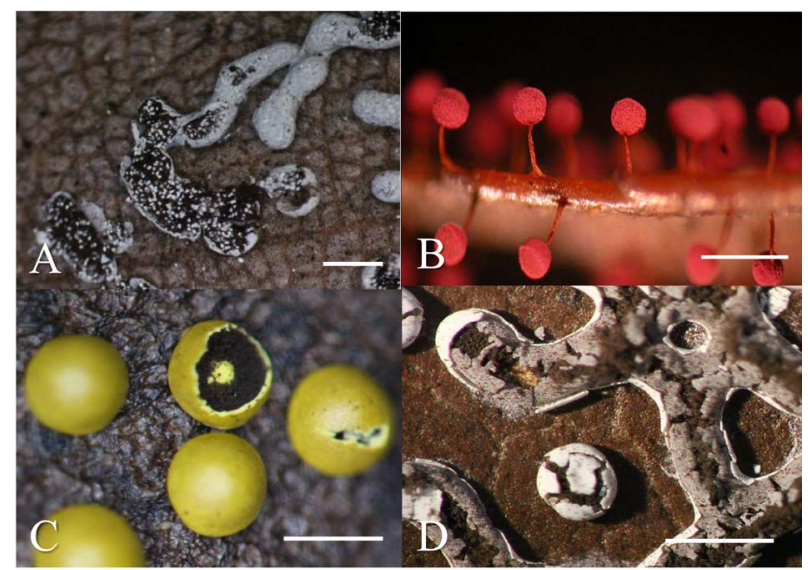

Figure 4. Myxomycete fruiting bodies of four species, of which relative abundance showed a correlation between litter $\mathrm{pH}$ in Table 4. (A) Physarum cinereum; (B) Physarum roseum; (C) Diderma simplex; (D) Diderma effusum. Bars: $1 \mathrm{~mm}$.

distribution. Each individual patch yielded a different assemblage of myxomycetes with high species diversity. Thus, the dominant tree types of each patch strongly influenced myxomycete distribution on the local spatial scale.

Species richness and diversity of foliicolous myxomycetes peaked in mixed evergreen/deciduous forests (Takahashi, 2013). The present study assessed five vegetation patches in a mixed forest, along approximately $300 \mathrm{~m}$ of a $65-\mathrm{m}$ elevation gradient. The topographical slope of the area was small, but nevertheless, there were important differences between study sites that identified non-random distributions for several species among the assemblages of myxomycetes. These species had distinct preferences for particular tree patches, confirmed by a lower myxomycete species evenness $\left(J^{\prime}\right)$ (i.e., P. melleum was abundant in the P. jamasakura patch and $D$. simplex was abundant in the I. pedunculosa patch). The mixed forest in western Japan contained diverse tree species that produce a variety of leaf litter types providing habitat heterogeneity for myxomycetes at a small scale.

\subsection{Species Occurrence on Different Leaf Litters}

Litter mass in a container closely resembles the humid conditions in windrow litter masses in hollow spots on the forest floor. Litter mass in a container served as a nursery and biotope for myxomycetes by replicating the natural conditions on the forest floor. The observed plasmodia of myxomycetes were fostered and grew in the humid conditions of the lower layers, after which matured plasmodia migrated to the upper layer and almost fruited on the surface leaves of the litter mass in the container. The previous study that surveyed the same climate region as the present study reported 45 species from seven litter types in different forests (Takahashi, 2013). The present study examined only five litter types in a mixed forest and noted a modest number of 33 species, $75 \%$ of the species estimated to be present (Sest 44). These results indicate that myxomycete species diversity was influenced by the variation in leaf litter, which depended on the tree type and species.

Major nutrients and decomposition rates in litters differ among tree species (Takeda et al., 1984). Decomposition of plant litter in which myxomycetes are living follows a sequential and complex process (Nioh et al., 1989; Berg \& Matzner, 1997). It is highly possible that bacteria, fungi, and antibiotic substances produced by plants influence the myxomycete habitats. Enzymatic activity of the plasmodium destroys carbohydrate substrates and was demonstrated as association with bacteria (Claudia \& Franz, 1988). Present investigation demonstrates that leaf litter from the dominant tree species constituted chemically and biologically varied habitats for myxomycetes, defining myxomycete diversity in the forest floor.

\subsection{Litter Variety in a Forest}

Tran et al. (2006) showed that in northern Thailand, mixed litters from two tree species provided a favorable habitat for the development of myxomycetes. These findings corroborate the current observations in a temperate Japanese forest, where mixed leaf litters derived from different tree species supported highly diverse myxomy- 
cete assemblages. The niche separation may be based on variation at a small scale and may correspond to tree species and resource partitioning. Härkönen (1981) demonstrated that Alnus leaf litter provided the highest abundance of myxomycetes, while that of Betula was the least favored. The nutrient concentration in foliar litter naturally depends on the tree type and leaching during initial leaf litter decomposition. For example, trees of the $\mathrm{N}_{2}$-fixing genus Alnus produce leaf litter with a high nitrogen concentration (Berg \& McClaugherty, 2010), which affects the composition of litter microbial communities.

Litter $\mathrm{pH}$ is another important environmental parameter that controls biotic factors. Physarum plasmodium formation occurs in a vegetative phase that is influenced by the incubation $\mathrm{pH}$ (Collins \& Tang, 1973). Furthermore, myxomycetes that occur mostly on the bark surface of living trees, shrubs, woody vines, and prairie and desert plants are divided into four $\mathrm{pH}$ groups along a broad spectrum of $\mathrm{pH} 3.5$ - 7.5 (Everhart et al., 2008).

The pH affects leaf litter decomposition (Tietema \& Wessel 1994), as well as the bacterial and fungal communities in soil (Rousk et al., 2009). The diversity and richness of soil bacteria were higher in neutral and lower in acidic soils (Fierer \& Jackson, 2006). Litter $\mathrm{pH}$ significantly influenced the location of myxomycete assemblages in NMDS ordination $(\rho=-0.900, p<0.05)$; the increase in litter acidity was associated with lower myxomycete species richness (Table $2, \rho=0.900, p<0.05$ ). Therefore, forest litter acidity was shown to influence myxomycete species distribution, as well as the microbes in soil.

\section{Conclusion}

The mixed forest in western Japan contained diverse tree species that produced a variety of leaf litter types providing habitat heterogeneity for myxomycetes on a small scale. The niche separation of species corresponded to patches of dominant tree species. This separation may depend on the resource partitioning in a forest. The nutrient concentration in foliar litter naturally depends on the tree type and leaching during initial leaf litter decomposition. The myxomycete species composition is context-specific and associated with the dominant tree species at a small scale in a forest. Distribution of myxomycete species was richest at the P. jamasakura litter site, which included both deciduous and evergreen trees in the mixed forest.

This study was the first to report that the $\mathrm{pH}$ of leaf litters and cellulolytic activity influenced the distribution of foliicolous myxomycetes in a forest. The nutrient supply from decomposing leaves is an important factor regulating the diversity of myxomycete species. Nutrient percolators and $\mathrm{pH}$ derived from the leaf litter of dominant trees should strongly influence the species distribution of myxomycetes in a forest. Further investigation of foliicolous myxomycetes and their micro-environments are needed in order to achieve a better understanding of the ecology of myxomycetes and terrestrial forest ecosystems.

\section{Acknowledgements}

I am grateful to the Himeji Nature Sanctuary of Himeji City in Hyogo Prefecture for the use of the forest area in the facilities. Furthermore, I would like to express my gratitude to Miss Yumi Iuchi, a nature guide officer in the forest park, and Ms. Takako Nomura, who conducted collecting leaf-litters and sampling of the myxomycete fruiting bodies in the present study. And also I would like to thank Dr. Yu Fukasawa of Tohoku University for improvement of my manuscript.

\section{References}

Berg, B., \& Matzner, E. (1997). The Effect of N Deposition on the Mineralization of C from Plant Litter and Humus. Environmental Reviews, 5, 1-25. http://dx.doi.org/10.1139/a96-017

Berg, B., \& McClaugherty, C. (2010). Plant Litter: Decomposition, Humus Formation, Carbon Sequestration (2nd ed.). Berlin: Springer.

Chao, A. (1984). Non-Parametric Estimation of the Number of Classes in a Population. Scandinavian Journal of Statistics, $11,265-270$.

Claudia, K., \& Franz, S. (1988). Cellulolytic, Xylanolytic, and Pectinolytic Activities of Myxomycetes. Journal of General and Applied Microbiology, 34, 321-332. http://dx.doi.org/10.2323/igam.34.321

Collins, O. R., \&Tang, H. (1973). Physarum polycepyarum: pH and Plasmodium Formation. Mycologia, 65, 232-236. http://dx.doi.org/10.2307/3757810

Everhart, S. E., Keller, H. W., \& Ely, J. S. (2008). Influence of Bark pH on the Occurrence and Distribution of Tree Canopy Myxomycete Species. Mycologia, 100, 191-204. http://dx.doi.org/10.3852/mycologia.100.2.191 
Fierer, N., \& Jackson, R. B. (2006). The Diversity and Biogeography of Soil Bacterial Communities. Proceedings of the National Academy of Sciences of the United States of America, 103, 626-631. http://dx.doi.org/10.1073/pnas.0507535103

Foissner, W. (2006). Biogeography and Dispersal of Microorganisms: A Review Emphasizing Protists. Acta Protozoologica, 45, 111-136.

Hammer, Ø., Harper, D. A. T., \& Ryan, P. D. (2001). PAST: Paleontological Statistics Software Package for Education and Data Analysis. Palaeontologia Electronica, 4, 9. http://palaeo-electronica.org/2001_1/past/issue1_01.htm

Härkönen, M. (1981). Myxomycetes Developed on Litter of Common Finnish Trees in Moist Chamber Cultures. Nordic Journal of Botany, 1, 791-794. http://dx.doi.org/10.1111/j.1756-1051.1981.tb01165.x

Ing, B. (1994). The Phytosociology of Myxomycetes. New Phytologist, 126, 175-201. http://dx.doi.org/10.1111/j.1469-8137.1994.tb03937.x

Jaccard, P. (1912). The Distribution of the Flora of the Alpine Zone. New Phytologist, 11, 37-50. http://dx.doi.org/10.1111/j.1469-8137.1912.tb05611.x

Kamono, A., Kojima, H., Matumoto, J., Kawamura, K., \& Fukui, K. (2009). Airborne Myxomycete Spores: Detection Using Molecular Techniques. Naturwissenschaften, 96, 147-151. http://dx.doi.org/10.1007/s00114-008-0454-0

Kenkel, N. C., \& Orloci, L. (1986). Applying Metric and Nonmetric Multidimensional Scaling to Ecological Studies: Some New Results. Ecology, 67, 919-928. http://dx.doi.org/10.2307/1939814

Lado, C. (2005-2015). An on Line Nomenclatural Information System of Eumycetozoa. http://eumycetozoa.com/data/index.php

Madelin, M. F. (1984). Myxomycetes, Microorganisms and Animals: A Model of Diversity in Animal Interactions. In J. M. Anderson, A. D. M. Rayner, \& W. H. Walton (Eds.), Invertebrate-Microbial Interactions (pp. 1-33). Cambridge: Cambridge University Press.

Ndiritu, G. G., Spiegel, F. W., \& Stephenson, S. L. (2009). Distribution and Ecology of the Assemblages of Myxomycetes Associated with Major Vegetation Types in Big Bend National Park, USA. Fungal Ecology, 2, 168-183. http://dx.doi.org/10.1016/i.funeco.2009.03.002

Nioh, I., Haruta, Y., \& Kawakami, H. (1989). Chemical and Microbial Changes of Leaf Litter of Japanese Cedar (Cryptomeria japonica) Decomposed in a Pot. Bulletin of Tokyo University Forests, 81, 21-37.

Pielou, E. C. (1966). The Measurement of Diversity in Different Types of Biological Collections. Journal of Theoretical Biology, 13, 131-144. http://dx.doi.org/10.1016/0022-5193(66)90013-0

Rayner, A. D. M., \& Boddy, L. (1988). Fungal Decomposition of Wood: Its Biology and Ecology. Amoebae and Myxomycetes (pp. 132-134). Chichester: John Wiley \& Sons.

Rojas, C., \& Stephenson, S. L. (2008). Myxomycete Ecology along an Elevation Gradient on Cocos Island, Costa Rica. Fungal Diversity, 29, 117-127.

Rousk, J., Brookes, P. C., \& Baath, E. (2009). Contrasting Soil pH Effects on Fungal and Bacterial Growth Suggest Functional Redundancy in Carbon Mineralization. Applied and Environmental Microbiology, 75, 1589-1596. http://dx.doi.org/10.1128/AEM.02775-08

Shannon, C. E., \& Weaver, W. (1963). The Mathematical Theory of Communication. Urbana, IL: University of Illinois Press.

Stephenson, S. L. (1989). Distribution and Ecology of Myxomycetes in Temperate Forests. II. Patterns of Occurrence on Bark Surface of Living Trees, Leaf Litter, and Dung. Mycologia, 81, 608-621. http://dx.doi.org/10.2307/3760136

Takahashi, K. (2010). Succession in Myxomycete Communities on Dead Pinus densiflora Wood in a Secondary Forest in Southwestern Japan. Ecological Research, 25, 995-1006. http://dx.doi.org/10.1007/s11284-010-0726-y

Takahashi, K. (2011). Occurrence of Myxomycetes Associated with Decaying State of Leaf-Litters in a Secondary Forest of Western Japan. Hikobia, 16, 95-103.

Takahashi, K. (2013). Myxomycete Distribution Varies among Leaf Litters of Different Vegetation in a Local Secondary Forest of Warm-Temperate Western Japan. Mycoscience, 54, 368-377. http://dx.doi.org/10.1016/j.myc.2013.01.001

Takeda, H., Prachaiyo, B., \& Tsutsumi, T. (1984). Comparison of Decomposition Rates of Several Tree Leaf Litters in a Tropical Forest in the North-East Thailand. Japanese Journal of Ecology, 34, 311-319.

Tietema, A., \& Wessel, W. W. (1994). Microbial Activity and Leaching during Initial Oak Leaf Litter Decomposition. Biology and Fertility of Soils, 18, 49-54. http://dx.doi.org/10.1007/BF00336444

Tran, H. T. M., Stephenson, S. L., Hyde, K. D., \& Mongkolporn, O. (2006). Distribution and Occurrence of Myxomycetes in Tropical Forests of Northern Thailand. Fungal Diversity, 22, 227-242.

Yamamoto, H., Ohtani, S., Tatsuyama, K., \& Akiyama, M. (1991). Preliminary Report on Cellulolytic Activity in the Antarctic Region (Extended Abstract). Proceedings of the NIPR Symposium on Polar Biology, 4, 179-182.

Yamamoto, Y. (1998). The Myxomycete Biota of Japan. Tokyo: Toyo Shorin. (In Japanese) 